Supporting Information for

\title{
Bifunctional Lewis Acid-Nucleophile Based Asymmetric Catalysis: Mechanistic Evidence for Imine Activation Working in Tandem with Chiral Enolate Formation in the Synthesis of $\beta$-Lactams
}

\author{
Stefan France, Meha H. Shah, Harald Wack, Anthony Weatherwax, and Thomas Lectka* \\ Department of Chemistry, New Chemistry Building, Johns Hopkins University, 3400 \\ North Charles Street, Baltimore, Maryland 21218
}

General. Unless otherwise stated, all reactions were carried out under strictly anhydrous, air-free conditions. All solvents were dried and distilled by standard procedures. The ${ }^{1} \mathrm{H}$, ${ }^{13} \mathrm{C}$ and ${ }^{19} \mathrm{~F}$ NMR spectra were acquired on a Varian Unity $400 \mathrm{MHz}$ Spectrometer. The ${ }^{1} \mathrm{H}(400 \mathrm{MHz})$ and ${ }^{13} \mathrm{C}$ chemical shifts $(101 \mathrm{MHz})$ are given in parts per million $(\delta)$ with respect to internal TMS standards or residual solvent peaks. Enantiomeric ratios were obtained using a Regis Technologies $(R, R)$-Whelk-01 chiral analytical HPLC column for $\beta$-lactams. All reagents used were commercially available and used as received. Catalyst $\mathbf{3} \mathbf{a}^{1}$ and imines $\mathbf{5} \mathbf{a}^{2}$ and $\mathbf{5} \mathbf{b}^{\mathbf{3}}$ were prepared according to literature procedures. $\beta$-Lactams $\mathbf{6 a - 6 h},{ }^{4}$ and catalyst $\mathbf{3 \mathbf { c } ^ { 5 }}$ were previously characterized.

General Procedure for the Tandem Nucleophile/Lewis Acid Promoted Synthesis of $\beta$-Lactams. To a suspension of $\operatorname{In}(\mathrm{OTf})_{3}(3 \mathrm{mg}, 0.013 \mathrm{mmol})$, benzoylquinine 3a $(5.6$ $\mathrm{mg}, 0.013 \mathrm{mmol})$ and proton sponge $4(28 \mathrm{mg}, 0.13 \mathrm{mmol})$ in toluene $(7.5 \mathrm{~mL})$ at $-78^{\circ} \mathrm{C}$ was added dropwise phenylacetyl chloride $1 \mathbf{a}(20 \mathrm{mg}, 0.13 \mathrm{mmol})$ in toluene $(0.5 \mathrm{~mL}){ }^{6}$ A solution of imine $5 \mathbf{a}(32 \mathrm{mg}, 0.13 \mathrm{mmol})$ in toluene $(1 \mathrm{~mL})$ was then added via syringe pump over $1 \mathrm{~h}$. The reaction was allowed to warm to room temperature over $6 \mathrm{~h}$, before it was quenched with $1 \mathrm{M} \mathrm{HCl}(3 \mathrm{~mL})$. The aqueous layer was extracted twice with $\mathrm{CH}_{2} \mathrm{Cl}_{2}$ and the combined organic layers were dried over $\mathrm{MgSO}_{4}$ and filtered through Celite. Absorption onto silica gel followed by column chromatography (15\% $\mathrm{Et}_{2} \mathrm{O} /$ hexanes) afforded product $\mathbf{6 a}$ in $95 \%$ yield $(46 \mathrm{mg})$ and $98 \% \mathrm{ee}^{7}$ ( $\mathrm{dr}$ 60:1 [cis:trans]).

Quinine-Triphenylborate Ether-In(OTf) $)_{2}$ Complex (3b). To a solution of $\mathrm{NaH}$ (136 $\mathrm{mg}, 3.39 \mathrm{mmol}, 60 \%$ dispersion in mineral oil) in $20 \mathrm{~mL}$ THF, a solution of quinine (1.0 $\mathrm{g}, 3.08 \mathrm{mmol})$ in $10 \mathrm{~mL}$ THF was added. The reaction was allowed to stir for $2 \mathrm{~h}$. Triphenylborane $(746 \mathrm{mg}, 3.08 \mathrm{mmol})$ in $3 \mathrm{~mL}$ THF was added and the solution was stirred for $18 \mathrm{~h}$. In(OTf $)_{3}$ was then added and the solution was stirred for another $18 \mathrm{~h}$. The complex was used without further purification to give $\beta$-lactam $6 \mathbf{a}$ in $70 \%$ yield with $98 \%$ ee. 
In(BArF $)_{3}$ Salt (8). $\mathrm{InCl}_{3}(400 \mathrm{mg}, 0.56 \mathrm{mmol})$ and $\mathrm{Na}(\mathrm{BArF})^{8}(4.2 \mathrm{mg}, 0.188 \mathrm{mmol})$ were stirred in $3 \mathrm{~mL} \mathrm{CH}_{3} \mathrm{CN}$ at room temperature until completely homogeneous. The solution was cooled to $0^{\circ} \mathrm{C}$ until a precipitate appeared, then filtered through a filter needle. The catalyst solution was used directly but can be concentrated to yield a white solid. $\beta$-Lactam 6a is formed in $80 \%$ yield and $95 \%$ ee.

5-Fluorosalicylic Acid Benzyl Ether. To a solution of 5-fluorosalicylic acid (0.5 g, 3.2 mmol) in $5 \mathrm{~mL}$ of DMF was added $1.3 \mathrm{~mL}$ of benzyl chloride $(11.2 \mathrm{mmol})$ and $2.2 \mathrm{~g}$ of powdered $\mathrm{K}_{2} \mathrm{CO}_{3}(16 \mathrm{mmol})$. The reaction was left to reflux for $1 \mathrm{~h}$ and diluted with water after it had cooled to RT. The organic layer was separated and used without purification. The yellow oil was dissolved in $3 \mathrm{~mL}$ of $\mathrm{MeOH}$ and treated with $40 \%$ aq. $\mathrm{NaOH}$ solution $(1.5 \mathrm{~mL})$. This solution was allowed to reflux for $2 \mathrm{~h}$ and then diluted with $5 \mathrm{~mL}$ of water. The reaction was acidified with conc. $\mathrm{HCl}$ at which point a precipitate crashed out. The ppt. was recovered and recrystallized $\left(\mathrm{MeOH} / \mathrm{H}_{2} \mathrm{O}\right)$ to yield $0.8 \mathrm{~g}$ of 2-benzyloxy-5-fluorobenzoic acid. The product was characterized by NMR. ${ }^{1} \mathrm{H}$ NMR $\left(\mathrm{CDCl}_{3}\right)$ \& $10.82(\mathrm{bs}, 1 \mathrm{H}) ; 7.81(\mathrm{~m}, 1 \mathrm{H}) ; 7.44(\mathrm{~m}, 4 \mathrm{H}) ; 7.18(\mathrm{~m}, 2 \mathrm{H}) ; 7.10(\mathrm{~m}, 1 \mathrm{H})$; $5.29(\mathrm{~s}, 2 \mathrm{H}) \mathrm{ppm} ;{ }^{13} \mathrm{C} \mathrm{NMR}\left(\mathrm{CDCl}_{3}\right) \delta 172.0,159.2,154.3,140.9,128.7,127.4,127.3$, 121.7, 118.1, 117.8, 115.6, 77.8 ppm. Anal Calcd for $\mathrm{C}_{14} \mathrm{H}_{11} \mathrm{O}_{3} \mathrm{C}, 68.05 ; \mathrm{H}, 4.50$. Found C, 68.01; H, 4.53 .

$\boldsymbol{O}$-(5-Fluorosalicyloyl) Quinine (3e). The 2-benzyloxy-5-fluoro-benzoic acid (0.8 g, 3.2 mmol) was dissolved in $10 \mathrm{~mL}$ of $\mathrm{CH}_{2} \mathrm{Cl}_{2}$ and then treated with $0.3 \mathrm{~mL}$ of oxalyl chloride $(3.5 \mathrm{mmol})$ at $0^{\circ} \mathrm{C}$. The reaction was left to warm to RT over $3 \mathrm{~h}$ at which point the solvent was removed in vacuo. A solution of the crude 2-benzyloxy-5-fluorobenzoylchloride $(3.2 \mathrm{mmol})$ in $5 \mathrm{~mL}$ of THF was added slowly to a solution of quinine (930 mg, $2.9 \mathrm{mmol})$, and $0.5 \mathrm{~mL}$ of $\mathrm{Et}_{3} \mathrm{~N}(3.5 \mathrm{mmol})$ in $10 \mathrm{~mL} \mathrm{THF}$ at $0^{\circ} \mathrm{C}$. It was allowed to warm to RT overnight. The solution was washed twice with a $10 \mathrm{M}$ aqueous $\mathrm{KOH}$ solution, washed once with brine, then the aqueous phase was extracted with EtOAc. Organics were combined, dried with $\mathrm{MgSO}_{4}$, filtered and concentrated. The product was purified by column chromatography $\left(99.5 \% \mathrm{EtOAc} / 0.5 \% \mathrm{Et}_{3} \mathrm{~N}\right)$. The purified product was redissolved in $20 \mathrm{~mL}$ EtOH and hydrogenated under standard conditions ( $\sim 40 \mathrm{psi}, 10 \mathrm{~mol} \% \mathrm{Pd} / \mathrm{C})$ for $3 \mathrm{~h}$. It was then filtered through a plug of celite, and concentrated. Absorption onto silica gel followed by column chromatography (5\% $\mathrm{EtOH} / \mathrm{EtOAc}$ ) afforded product $3 \mathbf{e}$ in a combined $90 \%$ yield (1.3 g). Off-white crystalline solid recrystallized from $\mathrm{Et}_{2} \mathrm{O} / \mathrm{CH}_{2} \mathrm{Cl}_{2}:{ }^{1} \mathrm{H}$ NMR $\left(\mathrm{CDCl}_{3}\right) \delta 8.65(\mathrm{~d}, 1 \mathrm{H}), 7.95(\mathrm{~d}, 1 \mathrm{H})$, $7.71(\mathrm{~s}, 1 \mathrm{H}), 7.42(\mathrm{~d}, 1 \mathrm{H}), 7.35(\mathrm{dd}, 1 \mathrm{H}), 7.19(\mathrm{~d}, 1 \mathrm{H}), 7.12(\mathrm{dd}, 1 \mathrm{H}), 6.81(\mathrm{~d}, 1 \mathrm{H}), 4.22$ (d, $1 \mathrm{H}), 3.9(\mathrm{~s}, 3 \mathrm{H}), 3.56-3.72(\mathrm{~m}, 4 \mathrm{H}), 3.2-3.3(\mathrm{~m}, 1 \mathrm{H}), 2.8-3.05(\mathrm{~m}, 2 \mathrm{H}), 1.70-2.00(\mathrm{~m}$, $4 \mathrm{H}), 1.26-1.54(\mathrm{~m}, 3 \mathrm{H}), 0.84(\mathrm{t}, 3 \mathrm{H}) \mathrm{ppm} ;{ }^{13} \mathrm{C}$ NMR $\left(\mathrm{CDCl}_{3}\right) \delta$ 175.6, 159.4, 158.6, $146.8,144.3,139.6,133.8,131.5,130.4,128.1,126.7,122.7,122.5,117.5,116.2,101.01$, 56.0, 55.4, 54.9, 40.2, 36.0, 26.5, 25.7, 25.0, 24.6, 20.3, 11.4 ppm; IR $\left(\mathrm{CHCl}_{3}\right)$ 2962, 2363, 2341, 1750, $1623 \mathrm{~cm}^{-1}$. Anal Calcd for $\mathrm{C}_{27} \mathrm{H}_{29} \mathrm{~N}_{2} \mathrm{O}_{4} \mathrm{C}, 69.08 ; \mathrm{H}, 6.29 ; \mathrm{N}, 6.03$. Found C, 69.05; H, 6.31; N, 6.07.

Preparation of catalyst In(III)-3c. To the quinine derivative 3c $(29 \mathrm{mg}, 0.0065 \mathrm{mmol})$ and $\mathrm{NaH}(1.6 \mathrm{mg}, 0.0065 \mathrm{mmol})$ was added minimal amount of THF $(<0.5 \mathrm{~mL})$. The 
solution was stirred for $15 \mathrm{~min}$. In most cases the slightly heterogeneous solution (excess $\mathrm{NaH}$ ) was filtered through disposable syringe filters to yield a clear and colorless solution. This was combined with neat $\operatorname{In}(\mathrm{OTf})_{3}(36 \mathrm{mg}, 0.0065 \mathrm{mmol})$ and the homogeneous yellow mixture was added according to the general reaction protocol.

$\boldsymbol{O}$-(2-Carboxyphenanthroloyl) Quinine (3g). To a solution of 2carboxyphenanthroline ${ }^{9}(336 \mathrm{mg}, 1.5 \mathrm{mmol})$ and DMF $(0.01 \mathrm{~mL}, 0.15 \mathrm{mmol})$ in $15 \mathrm{~mL}$ $\mathrm{CH}_{2} \mathrm{Cl}_{2}$, oxalyl chloride $(0.2 \mathrm{~mL}, 2.25 \mathrm{mmol})$ was added dropwise. The reaction mixture was allowed to stir until gas evolution ceased $(\sim 6 \mathrm{~h})$. The solution was concentrated, dissolved in $15 \mathrm{~mL}$ THF and fitted with a reflux condenser. Quinine (162 mg, $0.5 \mathrm{mmol})$ and $\mathrm{Et}_{3} \mathrm{~N}(101 \mathrm{mg}, 1 \mathrm{mmol})$ in $10 \mathrm{~mL}$ THF was added and the solution was allowed to reflux for 7 days. The mixture was concentrated in vacuo, dissolved in $\mathrm{CH}_{2} \mathrm{Cl}_{2}$ and filtered. The filtrate was concentrated and purified by column chromatography $(10 \%$ $\mathrm{MeOH} / \mathrm{CH}_{2} \mathrm{Cl}_{2}$ with $\left.1 \% \mathrm{Et}_{3} \mathrm{~N}\right)$ and recrystallized three times from $\mathrm{Et}_{2} \mathrm{O} /$ hexanes. ${ }^{1} \mathrm{H}$ $\operatorname{NMR}\left(\mathrm{CDCl}_{3}\right) \delta 9.10(\mathrm{dd}, 1 \mathrm{H}), 8.68(\mathrm{~d}, 1 \mathrm{H}), 8.42(\mathrm{q}, 2 \mathrm{H}), 8.33(\mathrm{dd}, 1 \mathrm{H}), 8.06(\mathrm{~d}, 1 \mathrm{H})$, 7.88-7.90 (m, 3H), $7.72(\mathrm{~m}, 2 \mathrm{H}), 7.46(\mathrm{~m}, 2 \mathrm{H}), 5.72(\mathrm{~m}, 1 \mathrm{H}), 5.16(\mathrm{~d}, 1 \mathrm{H}), 5.12(\mathrm{~d}, 1 \mathrm{H})$, $4.80(\mathrm{~m}, 1 \mathrm{H}), 4.24(\mathrm{~s}, 3 \mathrm{H}), 3.50-3.72(\mathrm{~m}, 4 \mathrm{H}), 3.32(\mathrm{~m}, 1 \mathrm{H}), 3.24(\mathrm{~m}, 1 \mathrm{H}), 2.85(\mathrm{~m}, 1 \mathrm{H})$, $2.78(\mathrm{~m}, 1 \mathrm{H}), 2.38(\mathrm{~m}, 1 \mathrm{H}), 2.10(\mathrm{~m}, 1 \mathrm{H}), 1.8(\mathrm{~m}, \mathrm{IH}) \mathrm{ppm} ;{ }^{13} \mathrm{C}\left(\mathrm{CDCl}_{3}\right) \delta 167.0,158.2$, $151.8,150.0,148.1,147.2$, 143.8, 142.7, 140.6, 135.9, 135.7, 131.2, 129.2, 128.0, 127.6, $126.4,126.3,121.6,120.8,120.3,114.4,78.5,60.1,56.0,54.5,50.5,38.6,33.2,28.4$ ppm.

Preparation of catalyst $\mathbf{Z n - 3 g}$. To a stirring solution of $\mathbf{3 g}(34 \mathrm{mg}, 0.065 \mathrm{mmol})$ in 5 $\mathrm{mL}$ ethanol:triethyl orthoformate $(4: 1, \mathrm{v} / \mathrm{v}), \mathrm{ZnBr}_{2}(15 \mathrm{mg}, 0.065 \mathrm{mmol})$ was added and the reaction mixture was stirred for $30 \mathrm{~min}$. The resulting solids were collected, washed with cold ethanol and dried under vacuum. The complex was used without further purification according to the general reaction procedure.

$\mathbf{N}$-(Ethoxycarbonylmethylidine)-2-methoxyaniline (5c). Freshly distilled $o$-methoxy aniline $(1.5 \mathrm{~mL}, 13.3 \mathrm{mmol})$ was dissolved in $25 \mathrm{~mL}$ of toluene. Ethyl glyoxylate $(2.7$ $\mathrm{mL}, 13.3 \mathrm{mmol}$ ) was added to the solution followed by a gross excess of anhydrous sodium sulfate. The reaction was left to stir at room temperature for $2 \mathrm{~h}$. The $\mathrm{Na}_{2} \mathrm{SO}_{4}$ was filtered off and the filtrate was concentrated down to yield a yellow oil. The oil was stored at $-30^{\circ} \mathrm{C}$ and showed no degradation. ${ }^{1} \mathrm{H}$ NMR $\left(\mathrm{CDCl}_{3}\right) \delta 7.94(\mathrm{~s}, 1 \mathrm{H}) ; 7.36(\mathrm{~d}$, $2 \mathrm{H}) ; 6.92(\mathrm{~d}, 2 \mathrm{H}) ; 4.42(\mathrm{q}, 2 \mathrm{H}) ; 3.85(\mathrm{~s}, 3 \mathrm{H}) ; 1.41(\mathrm{t}, 3 \mathrm{H}) \mathrm{ppm} ;{ }^{13} \mathrm{C}\left(\mathrm{CDCl}_{3}\right) \delta 165.1$, $161.3,152.9,135.6,128.4,123.1,122.5,115.3,61.1,55.9,14.2 \mathrm{ppm}$. Anal Calcd for $\mathrm{C}_{11} \mathrm{H}_{13} \mathrm{NO}_{3} \mathrm{C}, 63.76 ; \mathrm{H}, 6.32 ; \mathrm{N}, 6.76$. Found $\mathrm{C}, 63.72 ; \mathrm{H}, 6.31 ; \mathrm{N}, 6.78$.

1-p-Methoxyphenyl-3-phenyl-4-ethoxycarbonylazetidinone. ${ }^{1} \mathrm{H}$ NMR $\left(\mathrm{CDCl}_{3}\right) \delta 7.32$ $(\mathrm{m}, 7 \mathrm{H}) ; 6.89(\mathrm{~d}, 2 \mathrm{H}) ; 4.9(\mathrm{~d}, 1 \mathrm{H}) ; 4.84(\mathrm{~d}, 1 \mathrm{H}) ; 3.82(\mathrm{q}, 2 \mathrm{H}) ; 3.79(\mathrm{~s}, 3 \mathrm{H}) ; 0.8(\mathrm{t}, 3 \mathrm{H})$ ppm; ${ }^{13} \mathrm{C}\left(\mathrm{CDCl}_{3}\right) \delta 171.2,167.1,155.9,136.2,130.2,129.5,127.7,122.1,114.3,63.8$, 61.2, 56.5, 43.1, 13.9 ppm. Anal Calcd for $\mathrm{C}_{19} \mathrm{H}_{19} \mathrm{NO}_{4} \mathrm{C}, 70.14 ; \mathrm{H}, 5.89 ; \mathrm{N}, 4.31$. Found C, $70.11 ; \mathrm{H}, 5.92 ; \mathrm{N}, 4.29$.

1-o-Methoxyphenyl-3-phenyl-4-ethoxycarbonylazetidinone. ${ }^{1} \mathrm{H}$ NMR $\left(\mathrm{CDCl}_{3}\right) \delta 7.35$ $(\mathrm{m}, 7 \mathrm{H}) ; 6.92(\mathrm{~d}, 2 \mathrm{H}) ; 5.85(\mathrm{~d}, 2 \mathrm{H}) ; 5.72(\mathrm{~d}, 2 \mathrm{H}) ; 3.74(\mathrm{~s}, 3 \mathrm{H}) ; 3.6(\mathrm{q}, 2 \mathrm{H}) ; 1.2(\mathrm{t}, 3 \mathrm{H})$ 
ppm; ${ }^{13} \mathrm{C}\left(\mathrm{CDCl}_{3}\right) \delta 171.3,167.1,152.3,136.3,130.4,129.1,128.2,127.1,125.1,122.6$, 121.3, 63.2, 61.2, 55.9, 43.2, 14.0 ppm. Anal Calcd for $\mathrm{C}_{19} \mathrm{H}_{19} \mathrm{NO}_{4} \mathrm{C}, 70.14 ; \mathrm{H}, 5.89 ; \mathrm{N}$, 4.31. Found C, 70.17; H, 5.87; N, 4.28.

Competition Reaction with $5 \mathbf{b}$ and 5c. Proton sponge $(68.5 \mathrm{mg}, 0.32 \mathrm{mmol})$ was placed into a $25 \mathrm{~mL}$ round-bottomed flask along with BQ (13.7 $\mathrm{mg}, 0.032 \mathrm{mmol})$ and $\mathrm{In}(\mathrm{OTf})_{3}(18 \mathrm{mg}, 0.032 \mathrm{mmol})$. The solids were suspended in $5 \mathrm{~mL}$ of freshly distilled toluene and cooled to $-78^{\circ} \mathrm{C}$. To this mixture was added $0.04 \mathrm{~mL}$ of phenylacetyl chloride $(0.32 \mathrm{mmol})$ in $2 \mathrm{~mL}$ of toluene. Equal amounts of $\mathbf{5 b}$ and $\mathbf{5 c}$ were combined $(66.2 \mathrm{mg}, 0.32 \mathrm{mmol})$, dissolved in $3 \mathrm{~mL}$ of toluene and added to the reaction. After 15 min the reaction was quenched with $3 \mathrm{~mL}$ of $1 \mathrm{M} \mathrm{HCl}$. After extraction with dichloromethane ( $3 \times 5 \mathrm{~mL})$, the organics were combined, dried with $\mathrm{MgSO} 4$, and filtered through Celite. The filtrate was concentrated down to yield a tan residue. A $1 \mathrm{H}$ NMR of the crude residue was taken to determine the ratio of $\mathbf{6 b}$ to $\mathbf{6 c}$.

\section{Mechanistic Studies of Metal-3c Complexes}

NMR Experiment for Salicylate-Metal Binding. $80 \mathrm{mg}(0.17 \mathrm{mmol})$ of the catalyst $3 \mathbf{e}$ was heated with $0.08 \mathrm{~mL}(0.085 \mathrm{mmol})$ of diethylzinc $(1.1 \mathrm{M} /$ toluene $)$ to $50^{\circ} \mathrm{C}$ for $30 \mathrm{~min}$ and then concentrated in vacuo. Some of the residue $(20 \mathrm{mg})$ was dissolved in $0.5 \mathrm{~mL}$ $\mathrm{CDCl}_{3}$ and to this was added a drop of $\mathrm{CFCl}_{3}$ as an internal standard. A ${ }^{19} \mathrm{~F}$ NMR taken at RT showed a peak at $4.8 \mathrm{ppm}$ after which another 0.5 eq. of the catalyst was added to determine if there was rapid exchange. A similar experiment was done using $\operatorname{In}(\mathrm{OTf})_{3}$, but its complex was made according to the procedure for In(III)-3c with $0.04 \mathrm{mmol}$ of both the catalyst and $\mathrm{In}(\mathrm{OTf})_{3} \cdot{ }^{19} \mathrm{~F} \mathrm{NMR}\left(\mathrm{CDCl}_{3}\right) \delta 5.7 \mathrm{ppm}$.

Determination of Imine Concentration Effects. Three 10-mL flasks were set up in the following manner: To a suspension of $\mathrm{NaH}(11.0 \mathrm{mg}, 0.28 \mathrm{mmol}), 3 \mathrm{c}(5.5 \mathrm{mg}, 0.013$ $\mathrm{mmol})$, and 15 -crown-5 $(0.013 \mathrm{mmol})$ in toluene $(4.5 \mathrm{~mL})$ at $-78^{\circ} \mathrm{C}$ was added phenylacetyl chloride $1 \mathrm{a}(48.0 \mathrm{mg}, 0.31 \mathrm{mmol})$ in toluene $(1.0 \mathrm{~mL})$. The solution was allowed to stir at $-78^{\circ} \mathrm{C}$ for $6 \mathrm{~h}$. The $\alpha$-imino ester $5 \mathbf{a}(16.5 \mathrm{mg}, 0.065 \mathrm{mmol} ; 33 \mathrm{mg}$, $0.13 \mathrm{mmol} ; 66 \mathrm{mg}, 0.26 \mathrm{mmol})$ was then added in toluene $(4.0 \mathrm{~mL})$ to each of the reactions and allowed to react for $10 \mathrm{~min}$ at which time $3.0 \mathrm{~mL}$ of $1.0 \mathrm{M} \mathrm{HCl}$ was added to quench the reactions. The reactions were extracted with dichloromethane, dried with $\mathrm{MgSO}_{4}$ and concentrated. The resulting residues were subjected to column chromatography through a small plug of silica gel (10\% EtOAc/hexanes). The reactions were repeated with $10 \mathrm{~mol} \%$ of $\operatorname{In}(\mathrm{OTf})_{3}$ and the reaction time with the imine was reduced to $5 \mathrm{~min}$. For the reactions without $\mathrm{In}(\mathrm{OTf})_{3}$ the product yields were, $19 \mathrm{mg}, 26$ $\mathrm{mg}$, and $30 \mathrm{mg}$ for $0.5,1.0$, and 2.0 eq. of the $\alpha$-imino ester, respectively. With $\operatorname{In}(\mathrm{OTf})_{3}$, the reaction yielded $20 \mathrm{mg}, 26 \mathrm{mg}$, and $33 \mathrm{mg}$ for $0.5,1.0$, and 2.0 eq. of 5a, respectively.

Determination of Isotope Effects. Two $10-\mathrm{mL}$ flasks were set up in the following manner. $\mathrm{NaH}(11.0 \mathrm{mg}, 0.28 \mathrm{mmol}), 3 \mathrm{c}(5.5 \mathrm{mg}, 0.013 \mathrm{mmol})$, and 15-crown-5 (0.013 mmol) were suspended in $4.5 \mathrm{~mL}$ of toluene. The reactions were cooled to $-78^{\circ} \mathrm{C}$ and 
phenylacetyl chloride $(48.0 \mathrm{mg}, 0.31 \mathrm{mmol})$ was added to one reaction while $\alpha, \alpha-$ phenylacetyl chloride $-d_{2}(48.5 \mathrm{mg}, 0.31 \mathrm{mmol})$ was added to the other, each in $1.0 \mathrm{~mL}$ of toluene. The reactions were allowed to stir for $6 \mathrm{~h}$ at $-78^{\circ} \mathrm{C}$ and then the $\alpha$-imino ester (33.0 mg, $0.13 \mathrm{mmol}$ ) was added to each reaction in $2.0 \mathrm{~mL}$ of toluene. After $10 \mathrm{~min}, 3.0$ $\mathrm{mL}$ of $1.0 \mathrm{M} \mathrm{HCl}$ was added to quench the reactions. The reactions were extracted with dichloromethane, dried with $\mathrm{MgSO}_{4}$ and concentrated. The resulting residues were subjected to column chromatography through a small plug of silica gel $(10 \%$ EtOAc/hexanes). The reactions were repeated and quenched $10 \mathrm{~min}$ after imine addition. The reactions were repeated with $10 \mathrm{~mol} \% \mathrm{In}(\mathrm{OTf})_{3}$ and the reaction time with the imine was reduced to $5 \mathrm{~min}$. For the reactions with phenylacetyl chloride the product yields were, $25 \mathrm{mg}$ after $15 \mathrm{~min}, 15 \mathrm{mg}$ after $10 \mathrm{~min}$, and $25 \mathrm{mg}$ after $5 \mathrm{~min}$ (with $\operatorname{In}(\mathrm{OTf})_{3}$ ). Similarly, with phenylacetyl chloride- $d_{2}$ the yields of lactam product were, $31 \mathrm{mg}$ after 15 min, $18 \mathrm{mg}$ after $10 \mathrm{~min}$, and $30 \mathrm{mg}$ after $5 \mathrm{~min}$ (with $\mathrm{In}(\mathrm{OTf})_{3}$ ).

1 Pracejus, H.; Maetje, H.; J. Prakt. Chem. 1964, 24, 195-205

2 Tschaen, D. H.; Turos, E.; Weinreb, S. M. J. Org. Chem. 1984, 49, 5058-5064

3 Firestone, R. A.; Barker, P. L.; Pisano, J. M.; Ashe, B. M.; Dahlgren, M. E. Tetrahedron 1990, 46, 2255-2262.

4 Taggi, A. E.; Hafez, A. M.; Wack, H.; Young, B.; Ferraris, D.; Lectka, T. J. Am. Chem. Soc. 2002, 124, 6626-6635.

5 France, S.; Wack, H.; Hafez, A. M.; Taggi, A. E.; Witsil, D. R.; Lectka, T. Org. Lett. 2002, 4, 1603-1605.

6 For $6 \mathrm{~d}$ and $6 \mathrm{f}$, the acid chloride was added to a solution of proton sponge and $\mathrm{BQ}$ in $7.5 \mathrm{~mL}$ of toluene and stirred at $0^{\circ} \mathrm{C}$ for 30 min and then cooled to $-78^{\circ} \mathrm{C}$. A suspension of $\mathrm{In}(\mathrm{OTf}) 3$ and the imine $(1 \mathrm{~mL}$ toluene) was added via syringe pump over $1 \mathrm{~h}$

7 The ee's reported are for the $(\mathrm{R}, \mathrm{R})$ enantiomers unless otherwise stated.

8 Brookhart, M.; Grant, B.; Volpe, A. F., Jr. Organometallics 1992, 11, 3920-3922. (b) Chavez, I.; Alvarez,-Carena, A.; Molins, E.; Roig, A.; Maniukiewicz, W.; Arancibia, A.; Arancibia, V.; Brand, H.; Manuel Manriquez, J. J. Organomet. Chem. 2000, 601, 126-132.

9 Corey, E. J.; Borror, A. L.; Foglia, T. J. Org. Chem. 1965, 30, 288-290. 